\title{
PENGEMBANGAN PERANGKAT PEMBELAJARAN FISIKA DENGAN MODEL INKUIRI TERBIMBING UNTUK MELATIHKAN KETERAMPILAN PROSES SAINS SISWA SMA PADA MATERI FLUIDA STATIS
}

\author{
Putri Ayuningtyas ${ }^{1)}$, Soegimin W. W. ${ }^{2)}$, A. Imam Supardi ${ }^{3)}$. \\ ${ }^{1)}$ Mahasiswap Rogram Pendidikan Sains Program Pascasarjana Universitas Negeri Surabaya. \\ ${ }^{2), 3)}$ Dosen Pascasarjana Pendidikan Sains Universitas Negeri Surabaya. \\ E-mail: putriayuningtyas26@gmail.com
}

\begin{abstract}
This study aims to produce a feasible, practical, and effective Physics learning materials with guided inquiry models to facilitate high school students science process skills on the static fluids. The learning materials were try outed to the class XI SMA Kemala Bhayangkari 1 Surabaya in the second semester of the academic year 2013/2014 with the replication of three classes which are class XI-IPA 1, XI-IPA 2, and XI-IPA 3. This research is the development research, with four D models. The trial design using one-group pretest-posttest design. The results were obtained: (1) the validity of learning materials were good category; the readability student textbook and worksheets were good category; (2) learning performance was good category; student's activities were categorized to students centered learning; (3) students gave the positive mastery of learning with high gain scores; all students are quite able to practice skill process throught the performance test. Based on the result and discussion of this research, it can be concluded that the Physics learning materials with guided inquiry models to facilitate science process skills of high school students on the static fluids were feasible, practical, and effective to be used at learning process.
\end{abstract}

Keywords: Development of Learning Material, Guided Inquiry, Science Process Skills

Abstrak: Penelitian ini bertujuan untuk menghasilkan perangkat pembelajaran Fisika yang layak, praktis, dan efektif dengan model inkuiri terbimbing untuk melatihkan keterampilan proses sains siswa SMA pada materi fluida statis. Perangkat pembelajaran tersebut diujikan terhadap siswa kelas XI SMA Kemala Bhayangkari 1 Surabaya tahun pelajaran 2013/2014 dengan replikasi tiga kelas yaitu kelas XI-IPA 1, kelas XI-IPA 2, dan kelas XI-IPA 3. Penelitian ini merupakan penelitian pengembangan, dengan model 4-D. Rancangan ujicoba perangkat menggunakan one group pretest-posttest design. Hasil penelitian menunjukkan: (1) validitas perangkat pembelajaran berkategori baik; tingkat keterbacaan buku ajar siswa dan lembar kegiatan siswa berkategori baik; (2) keterlaksanaan RPP berkategori baik; aktivitas siswa menunjukkan pembelajaran yang berpusat pada siswa; (3) respon siswa positif terhadap proses pembelajaran; 93\% siswa mencapai ketuntasan hasil belajar dengan skor peningkatan yang tinggi; seluruh siswa sudah cukup mampu untuk berlatih keterampilan proses melalui tes kinerja. Berdasarkan hasil dan diskusi penelitian, dapat disimpulkan bahwa perangkat pembelajaran Fisika dengan model inkuiri terbimbing untuk melatihkan keterampilan proses sains siswa SMA pada materi fluida statis layak, praktis, dan efektif digunakan dalam pembelajaran.

Kata kunci: Pengembangan Erangkat Pembelajaran, Inkuiri Terbimbing, Keterampilan Proses Sains

\section{PENDAHULUAN}

Fisika merupakan salah satu cabang IPA (sains) yang mendasari perkembangan teknologi maju dan konsep hidup harmonis dengan alam. Fisika bertujuan agar siswa memiliki kemampuan antara lain: mengembangkan pengalaman untuk dapat merumuskan masalah, mengajukan dan menguji hipotesis melalui percobaan, merancang instrumen percobaan, mengumpulkan, mengolah dan menafsirkan data serta mengkomunikasikan hasil percobaan secara lisan dan tertulis (BSNP, 2007). Fisika merupakan sebuah kumpulan pengetahuan (a body of knowledge), cara atau jalan berpikir ( $a$ way of thinking), dan cara untuk penyelidikan (a way of investigating) (Collette dan Chiappetta, 1994). Proses pembelajaran Fisika bukan hanya memahami konsep-konsep Fisika, tetapi juga siswa belajar berpikir konstruktif melalui Fisika sebagai keterampilan proses sains, sehingga pemahaman siswa terhadap hakikat Fisika menjadi utuh, baik sebagai proses maupun sebagai produk (Lesmono, Supeno, Riani, 2012).

Siswa sekolah menengah memandang Fisika sebagai pelajaran yang sulit, menakutkan, kurang menyenangkan dan membosankan. Kondisi diruang kelas terlalu monoton, anak-anak dipaksa duduk dengan rapi selama berjam-jam mendengarkan guru 
mencurahkan ilmu, memungkinkan siswa merasa berada di dunia lain. Apa yang dialami siswa diruang kelas berbanding terbalik dengan kenyataan yang dialaminya. Kegembiraan, warna-warni kehidupan tidak lagi ditemukan diruang kelas, yang hanya ada buku, catatan dan sederet perintah guru. Kondisi ini akan melahirkan kebosanan sehingga dapat berpengaruh terhadap aktivitas belajar dan hasil belajar siswa (Triharyanti, 2012).

Pembelajaran yang berkualitas memerlukan suatu perangkat pembelajaran yang dapat membantu siswa memahami dan menguasai materi Fisika dengan baik. Implikasi dari pernyataan tersebut adalah agar guru dapat mengajar dengan baik, maka guru harus mempersiapkan perangkat pembelajaran sebelum kegiatan belajar mengajar dimulai. Dengan demikian, perangkat pembelajaran memegang peranan penting dalam kesuksesan proses pembelajaran guna mendukung kelancaran dalam kegiatan belajar mengajar.

Guru dituntut untuk membuat persiapan mengajar yang efektif dan efisien. Namun dalam kenyataannya, dengan berbagai alasan, banyak guru yang mengambil jalan pintas dengan tidak membuat persiapan ketika mau melakukan pembelajaran, sehingga guru mengajar tanpa persiapan. Mengajar tanpa persiapan, di samping merugikan guru sebagai tenaga profesional juga akan sangat mengganggu perkembangan siswa. Untuk membuat perencanaan yang baik dan dapat menyelenggarakan proses pembelajaran yang ideal, setiap guru harus mengetahui unsur-unsur perencanaan yang baik, antara lain: mengidentifikasi kebutuhan siswa, tujuan pembelajaran yang hendak dicapai, berbagai strategi dan skenario yang relevan digunakan untuk mencapai tujuan, dan kriteria evaluasi (Hunt, dalam Majid, 2006).

Seorang guru perlu mempersiapkan perangkat pembelajaran. Perangkat pembelajaran adalah sekumpulan media atau sarana yang membantu dan memudahkan proses belajar mengajar (PBM) untuk mencapai tujuan yang sudah ditentukan (Ibrahim, 2002). Perangkat pembelajaran diibaratkan seperti "segitiga emas pembelajaran". Segitiga emas pembelajaran memuat tujuan belajar, pengalaman belajar, dan prosedur evaluasi, yang saling berkaitan antara satu dengan yang lainnya. Serangkaian perangkat pembelajaran yang berkualitas, perlu dikembangkan melalui penelitian pengembangan. Perangkat pembelajaran yang diperlukan dalam mengelola PBM berupa: Silabus, Rencana Pelaksanaan Pembelajaran (RPP), Buku Ajar Siswa (BAS), Lembar Kegiatan Siswa (LKS), Penilaian Hasil Belajar, serta Media Pembelajaran (Ibrahim, 2002).

Kurikulum 2013 mengamanatkan esensi pendekatan ilmiah dalam pembelajaran. Pendekatan ilmiah diyakini sebagai titian emas perkembangan dan pengembangan sikap, keterampilan, dan pengetahuan siswa. Metode ilmiah merujuk pada teknik-teknik investigasi atas fenomena atau gejala, memperoleh pengetahuan baru, atau mengoreksi dan memadukan pengetahuan sebelumnya. Untuk dapat disebut ilmiah, metode pencarian (method of inquiry) harus berbasis pada bukti-bukti dari objek yang dapat diobservasi, empiris, dan terukur dengan prinsip-prinsip penalaran yang spesifik. (Mendikbud, 2013)

Pembelajaran Fisika yang berkaitan dengan kerja ilmiah, sangat tepat jika guru memilih dan menerapkan model inkuiri. Untuk materi tertentu, guru perlu memberikan kesempatan kepada siswa untuk mengembangkan rasa ingin tahunya dan memberikan peluang pada mereka untuk menemukan sendiri jawaban atas rasa keingintahuannya, bukan justru membunuh rasa keingintahuan siswa. Untuk menumbuhkan rasa keingintahuan dan keterampilan siswa dalam menemukan berbagai jawaban atas pertanyaan-pertanyaan tersebut, guru perlu memberi bimbingan, terlebih kepada siswa yang belum mampu melakukan langkah-langkah kerja ilmiah.

Proses pembelajaran pada kurikulum 2013 untuk jenjang SMA dilaksanakan menggunakan pendekatan ilmiah (scientific). Pembelajaran scientific tidak hanya memandang hasil belajar sebagai muara akhir, namum proses pembelajaran dipandang sangat penting. Dalam proses pembelajaran siswa dituntut agar berperan aktif terutama dalam kegiatan penemuan, sedangkan guru yang semula bertindak sebagai sumber belajar beralih fungsi menjadi seorang fasilitator kegiatan pembelajaran yang berperan mengarahkan (membimbing) siswa untuk memecahkan masalahmasalah yang dihadapi dalam belajar atau menemukan sendiri konsep-konsep yang sedang dipelajari. Pembelajaran scientific menekankan pada keterampilan proses (Mendikbud, 2013). Oleh karena itu, keberhasilan pembelajaran sains di sekolah dapat diukur dari dua aspek penting yaitu dari proses ilmu pengetahuan dan ilmu pengetahuan produk (Supriyatman dan Sukarno, 2014).

Hasil diskusi yang telah dilakukan dengan guru Fisika SMA Kemala Bhayangkari 1 Surabaya dapat diungkap bahwa:

1. Belum tersedianya perangkat pembelajaran Fisika berbasis pendekatan ilmiah (scientific).

2. Pelaksanaan pembelajaran Fisika hanya menekankan pada pemahaman konsep, penguasaan teori, dan pembahasan soal. Tujuan utama pembelajaran Fisika adalah siswa bisa mengerjakan soal.

3. Kegiatan praktikum belum mampu melatihkan keterampilan proses sains seperti merumuskan masalah, merumuskan hipotesis, menentukan 
variabel percobaan, merancang percobaan, dan kegiatan lain yang dapat melatihkan keterampilan proses sains. Sehingga, keterampilan proses sains yang ada pada siswa tidak tampak.

Fenomena di atas merupakan kondisi nyata di lapangan dalam proses belajar mengajar Fisika, meskipun tidak semua sekolah mengalami keadaan yang sama. Menurut hasil pengamatan Wiyanto (2006) menunjukkan bahwa pada umumnya pembelajaran Fisika cenderung monoton dengan aktivitas sains termasuk rendah. Keadaan seperti inilah yang menjadi permasalahan yang menjadi penyebab masih rendahnya hasil belajar siswa, termasuk keterampilan proses sains siswa (Suwasono, 2011).

Mengingat pentingnya keterampilan proses sains dalam pembelajaran Fisika, maka salah satu upaya untuk melatihkan keterampilan proses sains siswa adalah melalui pembelajaran dengan model inkuiri terbimbing. Menurut Bonnstetter dalam Inquiry: Learning from the Past with an Eye on the Future mengungkapkan bahwa: Inkuiri terbimbing masih memegang peranan guru dalam memilih materi atau bahasan, pertanyaan dan menyediakan materi, akan tetapi siswa diharuskan untuk mendesain atau merancang penyelidikan, menganalisa hasil, dan sampai pada kesimpulan.

Menurut Herdian (2010), inkuiri terbimbing yaitu model pembelajaran di mana guru membimbing siswa melakukan kegiatan dengan memberi pertanyaan awal dan mengarahkan pada suatu diskusi. Guru mempunyai peran aktif dalam menentukan permasalahan dan tahaptahap pemecahannya. Dengan model pembelajaran ini siswa belajar lebih beorientasi pada bimbingan dan petunjuk dari guru hingga siswa dapat memahami konsep-konsep pelajaran, siswa akan dihadapkan pada tugas-tugas yang relevan untuk diselesaikan baik melalui diskusi kelompok maupun secara individual agar mampu menyelesaikan masalah dan menarik suatu kesimpulan secara mandiri.

Fluida statis merupakan salah satu materi yang ada pada mata pelajaran Fisika yang cocok diajarkan dengan model inkuiri terbimbing. Alasan pertama pemilihan materi ini karena materi ini dapat diajarkan di semua sekolah termasuk sekolah yang minim dengan peralatan laboratorium. Alasan yang kedua memilih materi ini karena mencakup konsep dan aplikasi hukum Pascal dan hukum Archimedes yang sering dijumpai siswa dalam kehidupan sehari-hari. Model pembelajaran inkuiri terbimbing diharapkan menjadi salah satu model pembelajaran yang dapat meningkatkan hasil belajar dan melatihkan keterampilan proses sains siswa.

Berdasarkan uraian di atas, maka penelitian tentang pengembangan perangkat pembelajaran Fisika dengan model inkuiri terbimbing yang bertujuan untuk melatihkan keterampilan proses sains siswa perlu dilaksanakan. Untuk itu peneliti mengajukan penelitian dengan judul, "Pengembangan Perangkat Pembelajaran Fisika dengan Model Inkuiri Terbimbing untuk Melatihkan Keterampilan Proses Sains Siswa SMA pada Materi Fluida Statis".

Secara umum, tujuan penelitian ini adalah untuk menghasilkan perangkat pembelajaran fisika model inkuiri terbimbing yang valid, praktis, dan efektif untuk melatihkan keterampilan proses sains siswa SMA.

\section{METODE PENELITIAN}

Jenis Penelitian ini adalah penelitian pengembangan karena dikembangkan perangkat pembelajaran Fisika dengan model inkuiri terbimbing untuk melatihkan keterampilan proses sains siswa SMA pada materi fluida statis. Perangkat pembelajaran yang dikembangkan terdiri dari Rencana Pelaksanaan Pembelajaran (RPP), Lembar Kegiatan Siswa (LKS), Buku Ajar Siswa (BAS), dan Tes Hasil Belajar, dan Tes Kinerja (Keterampilan Proses). Disamping itu juga dilengkapi dengan instrumen yang diperlukan dalam penelitian ini yaitu lembar validasi perangkat pembelajaran, lembar pengamatan keterlaksanaan RPP, lembar pengamatan aktivitas siswa, angket respon siswa, tes hasil belajar pengetahuan, tes kinerja (keterampilan proses), serta lembar pengamatan hambatan-hambatan yang dihadapi selama KBM. Perangkat akan diterapkan dalam pembelajaran di kelas dan datanya dianalisis secara deskriptif. Subyek penelitian ini adalah perangkat pembelajaran Fisika dengan model inkuiri terbimbing untuk melatihkan keterampilan proses sains siswa SMA pada materi fluida statis. Perangkat pembelajaran diterapkan pada tiga kelas replikasi yaitu XI-IPA 1, XI-IPA 2, dan XIIPA 3 SMA Kemala Bhayangkari 1 Surabaya semester genap tahun pelajaran 2013/2014.

Model pengembangan perangkat yang digunakan dalam penelitian ini mengacu pada model 4-D (Four - D Model) dari Thiagarajan, et al. (Ibrahim, 2002). Prosedur pengembangan perangkat model ini terdiri dari empat tahap yaitu pendefinisian (define), perencanaan (design), pengembangan (develop), dan penyebaran (disseminate). Namun dalam penelitian ini pengembangan perangkat dilakukan hanya sampai pada tahap yang ketiga yakni tahap pengembangan (develop). Model ini dipilih karena tampak lebih terperinci tahapan-tahapannya, sistematis, dan terarah, sehingga memudahkan bagi peneliti untuk mengaplikasikannya. Model 4-D tersebut dapat dilihat pada Gambar 1.

Rancangan uji coba perangkat pembelajaran yang digunakan adalah One Group Pretest - Posttest Design (Prabowo, 2011). Rancangan uji coba perangkat dapat 
digambarkan sebagai berikut:

$$
\begin{array}{lll}
U_{1} & \mathbf{L} & U_{2} \\
\hline
\end{array}
$$

Dengan:

$\mathrm{U}_{1}$ : Uji Awal, untuk mengetahui tingkat
penguasaan siswa terhadap materi
pembelajaran sebelum dengan perlakuan
(pretest).

L : Memberikan perlakuan pada siswa, yaitu pembelajaran dengan model inkuiri terbimbing untuk melatihkan keterampilan proses sains siswa

$\mathrm{U}_{2}$ :Uji Akhir, untuk mengetahui hasil belajar dan tingkat penguasan materi pembelajaran sesudah perlakuan (posttest)

Teknik pengumpulan data digunakan untuk memperoleh bahan-bahan yang relevan, akurat, dan dapat digunakan dengan tepat sesuai tujuan penelitian. Teknik pengumpulan data yang digunakan dalam penelitian ini adalah: (1) observasi; (2) angket; dan (3) pemberian tes.

\section{A. Teknik Analisis Data}

Analisis data yang digunakan dalam penelitian ini adalah:

\section{Analisis validitas Peragkat Pembelajaran}

Perangkat pembelajaran yang terdiri dari RPP, Buku Ajara Siswa (BAS), LKS, Tes Hasil Belajar Pengetahuan, dan Tes Kinerja Siswa (Keterampilan Proses) yang dikembangkan selanjutnya ditelaah oleh pembimbing kemudian di validasi oleh validator untuk memberikan penilaian terhadap kelayakan untuk dijadikan perangkat pembelajaran. Dalam penelitian ini passing grade adalah skor rata-rata $(\mathrm{P})$ dari hasil penilaian para validator, kemudian disesuaikan dengan kriteria penilaian perangkat sebagai berikut:

Tabel 1. Kriteria Penilaian Perangkat Pembelajaran

\begin{tabular}{|c|c|}
\hline Interval Skor & Kategori Penilaian \\
\hline $3,5 \leq \mathrm{P} \leq 4,0$ & Baik / Valid \\
\hline $2,5 \leq \mathrm{P}<3,5$ & Cukup Baik / Cukup Valid \\
\hline $1,5 \leq \mathrm{P}<2,5$ & Kurang Baik/ Kurang Valid \\
\hline $1,0 \leq \mathrm{P}<1,5$ & Tidak Baik/ Tidak Valid \\
\hline
\end{tabular}

(Diadaptasi dari Ratumanan \& Laurens, 2006)

2. Analisis keterbacaan Buku Ajar Siswa (BAS) dan LKS

Tingkat keterbacaan merupakan gambaran bagaimana tingkat pembacaan siswa terhadap buku ajar dan LKS yang telah dikembangkan. Teknik analisis secara deskriptif kuantitatif dengan menggunakan rumus berikut:

$$
\mathrm{P}=\frac{\Sigma \mathrm{K}}{\Sigma \mathrm{N}} \times 100 \%
$$

(Hartati, 2014)

Keterangan:

P : Persentase keterbacaan BAS dan LKS

$\Sigma \mathrm{K}$ : Jumlah aspek keterbacaan siswa

$\Sigma \mathrm{N}$ : Jumlah total aspek keterbacaan siswa

\section{Analisis keterlaksanaan RPP}

Penilaian dan pengamatan dilakukan setiap kali tatap muka oleh dua orang pengamat. Teknik analisis data keterlaksanaan RPP dilakukan secara deskriptif kuantitatif dengan teknik persentase sebagai berikut:

Keterangan:

$$
\mathrm{P}=\frac{\Sigma \mathrm{A}}{\Sigma \mathrm{N}} \times 100 \%
$$

$$
\begin{aligned}
& \mathrm{P}: \text { Persentase keterlaksanaan RPP } \\
& \Sigma \mathrm{A}: \text { Jumlah aspek yang terlaksana } \\
& \Sigma \mathrm{N}: \text { Jumlah keseluruhan aspek yang diamati }
\end{aligned}
$$

Hasil pengamatan keterlaksanaan pembelajaran dianalisis dengan menggunakan analisis deskriptif kualitatif dengan cara menghitung hasil pengamatan, dihitung berdasarkan skor rata-rata tiap bagian untuk tiap RPP dan dikonversi menggunakan kriteria sebagai berikut:

$$
\begin{aligned}
& 1,00-1,99=\quad \text { tidak baik } \\
& 2,00-2,99=\quad \text { kurang baik } \\
& 3,00-3,49=\text { cukup baik } \\
& 3,50-4,00=\text { baik }
\end{aligned}
$$

\section{Analisis Pengamatan Aktivitas Siswa}

Aktivitas siswa adalah segala aktivitas yang dilakukan oleh siswa selama KBM berlangsung dan dinilai oleh dua pengamat dengan menggunakan instrumen yang disediakan. Aktivitas yang diamati meliputi: a) mendengarkan penjelasan guru, b) membaca bahan ajar, c) merumuskan masalah, d) merumuskan hipotesis, e) mengidentifikasi variabel, f) melaksanakan percobaan, g) mempresentasikan hasil percobaan, h) bertanya dan menanggapi pertanyaan teman/kelompok/guru, i) berperilaku tidak relevan.

Data yang diperoleh selanjutnya dipersentasekan menggunakan rumus sebagai berikut:

$$
\mathrm{P}=\frac{\mathrm{F}}{\mathrm{N}} \times 100 \%
$$

Keterangan:

$\mathrm{P}$ : Jumlah nilai dalam persen

F : Frekuensi dalam menit aktivitas siswa yang diamati

$\mathrm{N}$ : Jumlah aktivitas keseluruhan dalam menit (Djamarah, 2002 dalam Hartati, 2014) 


\section{Analisis Kendala-kendala selama Kegiatan Belajar Mengajar}

Data yang diperoleh dari lembar pengamatan kendala atau hambatan yang ditemui dilapangan selama KBM dideskripsikan dan dicari solusinya untuk memperbaiki kendala-kendala yang ditemukan.

\section{Analisis Respon Siswa}

Angket respon siswa digunakan untuk mengetahui pendapat siswa terhadap penerapan perangkat pembelajaran yang dikembangkan. Respon siswa dianalisis secara deskriptif dengan rumus persentase sebagai berikut:

$$
\mathrm{P}=\frac{\Sigma \mathrm{R}}{\Sigma \mathrm{N}} \times 100 \%
$$

Keterangan:

$$
\begin{aligned}
& \mathrm{P}: \text { Persentase respon siswa } \\
& \Sigma \mathrm{R}: \text { Jumlah respon } \\
& \Sigma N: \text { Jumlah keseluruhan respon }
\end{aligned}
$$

(Hartati, 2014)

7. Analisis ketuntasan belajar Aspek Pengetahuan

Ketuntasan belajar siswa dianalisis secara deskriptif kuantitatif, meliputi:

a. Ketuntasan Indikator

Ketuntasan indikator dihitung dengan menggunakan rumus:

Ketuntasan indikator

$$
=\frac{\Sigma \text { skor ketercapaian tiap indikator }}{\Sigma \text { skor indikator dalam KD }} \times 100 \%
$$

Suatu indikator dikatakan tuntas apabila $75 \%$ siswa mencapai ketuntasan indikator. Rumus ketuntasan indikator mengacu pada BSNP (2006).

b. Ketuntasan Individual

Analisis untuk menentukan ketuntasan belajar siswa dapat dihitung dengan menggunakan persamaan sebagai berikut:

Pindividual

$$
=\left[\frac{\text { jumlah skor yang diperoleh siswa }}{\text { jumlah skor maksimum }}\right] \times 100 \%
$$

Hasil belajar siswa dapat dikatakan tuntas belajarnya secara individu apabila memenuhi KKM yang telah disepakati bersama guru bidang studi. Sebagai standar ketuntasan hasil belajar siswa secara individual ditetapkan sebesar 75 .

Data hasil pretest dan posttest siswa dilakukan analisis $N$-Gain. Gain menunjukkan perbedaan pengetahuan fisika siswa sebelum dan setelah perlakuan.

$$
\langle\mathrm{g}\rangle=\frac{\mathrm{S}_{\text {post }}-\mathrm{S}_{\text {pret }}}{\mathrm{S}_{\max }-S_{\text {pret }}}
$$

Keterangan:

$$
\begin{aligned}
& \langle\mathrm{g}\rangle=\text { nilai gain } \\
& S_{\text {pret }}=\text { nilai pre-test } \\
& S_{\text {post }}=\text { nilai post-test } \\
& S_{\max }=\text { nilai maksimal. }
\end{aligned}
$$

Selanjutnya dari hasil perhitungan $N$-gain tersebut kemudian dikonversi dengan kriteria seperti berikut:

Tabel 2. Kriteria Normalized Gain

\begin{tabular}{|c|c|}
\hline Skor $N$-Gain & $\begin{array}{c}\text { Kriteria } \text { Normalized } \\
\text { Gain }\end{array}$ \\
\hline $0.70<N$-Gain & Tinggi \\
\hline $0.30 \leq N$-Gain $\leq 0.70$ & Sedang \\
\hline$N$-Gain $<0.30$ & Rendah \\
\hline
\end{tabular}

(Hake, 1999)

\section{Analisis Keterampilan Proses Siswa}

Tes kinerja digunakan untuk mengetahui penguasaan siswa terhadap keterampilan proses sains. Ketuntasan tes kinerja ini merujuk pada KKM yaitu lebih besar atau sama dengan 75. Ketuntasan belajar siswa dapat dihitung dengan menggunakan persamaan sebagai berikut:

$$
\text { KTK }=\frac{\text { jumlah skor yang diperoleh }}{\text { jumlah skor maksimum }} \times 100 \%
$$

Keterangan: $\mathrm{KTK}=$ Ketuntasan tes kinerja.

Langkah-langkah pengembangan perangkat pembelajaran dengan model inkuiri terbimbing dideskripsikan pada diagram alur pada Gambar 1. 


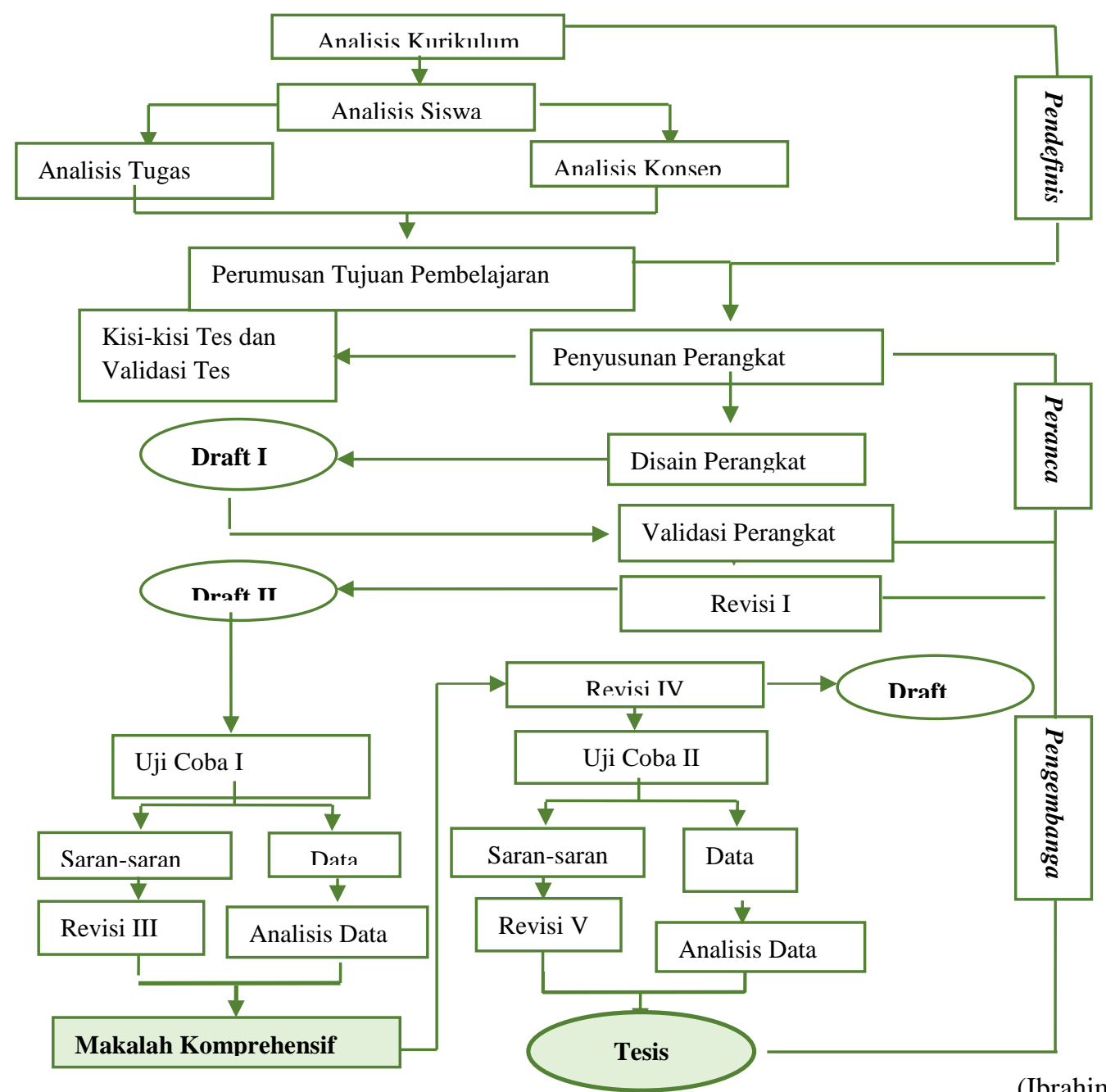

Gambar 1. Diagram alir pengembangan perangkat pembelajaran diadaptasi model 4-D

\section{HASIL PENELITIAN DAN DISKUSI}

\section{A. Hasil Kelayakan Perangkat}

1. Hasil validasi perangkat pembelajaran

Hasil pengembangan perangkat pembelajaran fisika model inkuiri terbimbing yang dikembangkan valid untuk digunakan dalam pembelajaran fisika untuk melatihkan keterampilan proses sains siswa.

Tabel 3. Hasil validasi perangkat pembelajaran fisika

\begin{tabular}{|l|l|c|c|c|}
\hline No & Jenis Perangkat & $\begin{array}{c}\text { Nilai } \\
\text { rata- } \\
\text { rata }\end{array}$ & Kategori & $\begin{array}{c}\text { Reliabil } \\
\text { itas }\end{array}$ \\
\hline 1 & RPP & 3,79 & Baik & $100 \%$ \\
\hline 2 & BAS & 3,54 & Baik & $99,37 \%$ \\
\hline 3 & LKS & 3,59 & Baik & $98,70 \%$ \\
\hline & $\begin{array}{l}\text { Tes Hasil } \\
\text { Belajar } \\
\text { Pengetahuan } \\
\text { a. Validitas Isi } \\
\text { b. Validitas } \\
\text { Bahasa dan } \\
\text { Penulisan } \\
\text { Soal }\end{array}$ & 3,60 & $\begin{array}{c}\text { Valid } \\
\text { Dapat } \\
\text { dipahami }\end{array}$ & $95,80 \%$ \\
\hline 5 & $\begin{array}{l}\text { Tes Kinerja } \\
\text { Keterampilan } \\
\text { Proses) }\end{array}$ & 3,70 & Valid & $98,80 \%$ \\
\hline
\end{tabular}

\section{Keterbacaan BAS dan LKS}

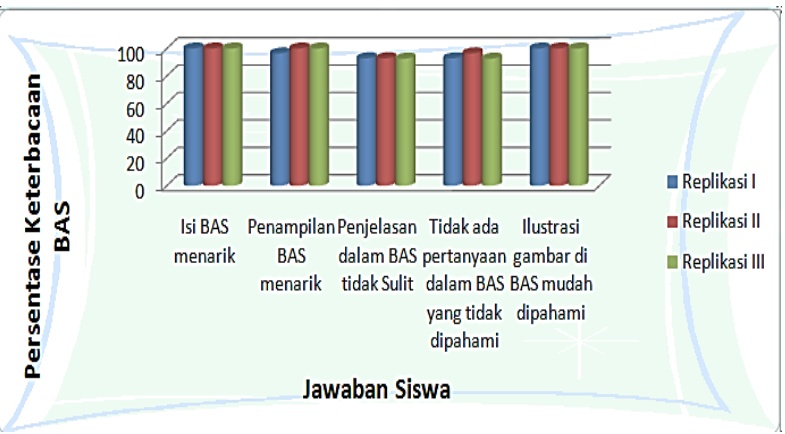

Gambar 2. Persentase keterbacaan BAS

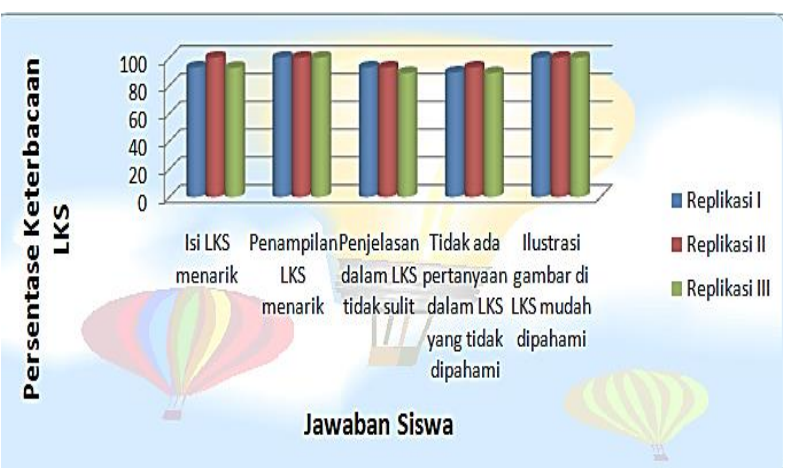

Gambar 3. Persentase keterbacaan LKS 
Berdasarkan hasil penilaian, keterbacaan BAS dan LKS secara umum berkategori baik dan layak digunakan dalam pembelajaran.

\section{B. Kepraktisan Perangkat Pembelajaran \\ 1. Keterlaksanaan RPP}

Semua tahap-tahap kegiatan yang ada di dalam RPP di kelas Replikasi I terlaksana dan secara rata-rata keseluruhan skor keterlaksanaannya adalah 3.60 dengan kategori baik. dan rata-rata reliabilitas $97.33 \%$.

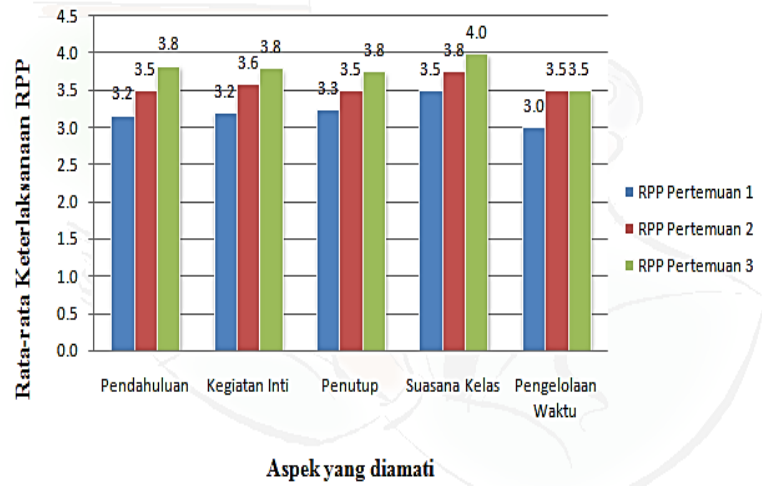

Gambar 4. Keterlaksanaan RPP pada kelas replikasi I

Semua tahap-tahap kegiatan yang ada di dalam RPP di kelas Replikasi II terlaksana dan secara rata-rata keseluruhan skor keterlaksanaannya adalah 3.70 dengan kategori baik. dan rata-rata reliabilitas $96.89 \%$

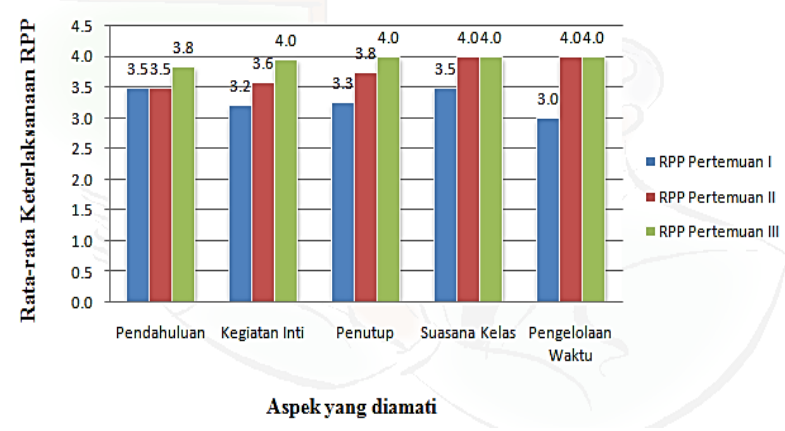

Gambar 5. Katerlaksanaan RPP pada kelas replikasi II

Semua tahap-tahap kegiatan yang ada di dalam RPP di kelas Replikasi III terlaksana dan secara ratarata keseluruhan skor keterlaksanaannya adalah 3.50 dengan kategori baik. dan rata-rata reliabilitas $96.33 \%$.

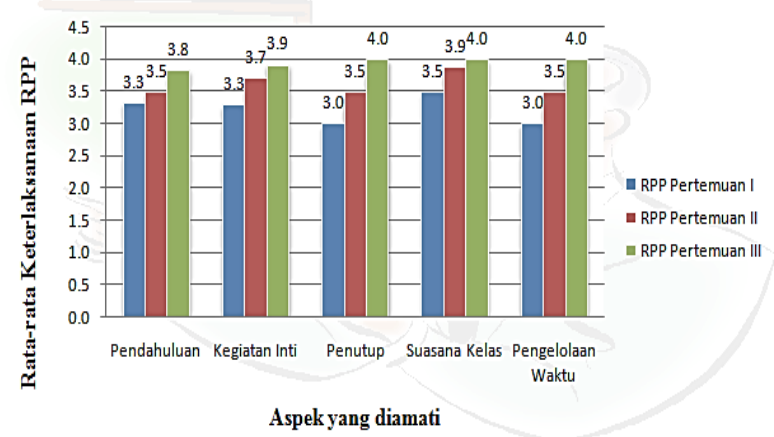

Gambar 6. Keterlaksanaan RPP pada kelas replikasi III
Rata-rata skor keterlaksanaan RPP kelas replikasi I, II, dan III yang meliputi pendahuluan, kegiatan inti, penutup, dan suasana kelas berkategori baik. Pengelolaan waktu dalam pembelajaran belum optimal pada pertemuan pertama, Hal ini disebabkan karena siswa merasa asing/tidak terbiasa dengan pembelajaran inkuiri terbimbing, sehingga membutuhkan waktu cukup lama untuk menjelaskan hal yang baru dalam proses pembelajaran.

Keterlaksanaan RPP yang baik menunjukkan bahwa guru mampu mengelola pembelajaran sesuai dengan tahapan-tahapan model pembelajaran inkuiri terbimbing. Guru mampu menggiring siswa ke dalam situasi pembelajaran inkuiri terbimbing, sehingga siswa dapat menemukan sendiri konsep materi fluida statis melalui penyelidikan dengan benar. Hal ini sesuai dengan teori Scaffolding Vygotsky tentang konsep pembelajaran dengan bantuan, yang menyatakan bahwa guru seharusnya memandu proses pembelajaran, sehingga siswa dapat menguasai secara tuntas keterampilan-keterampilan dengan fungsi kognitif yang lebih tinggi (dalam Nur, 2011). Hal ini juga didukung oleh Bruner (dalam Nur, 2011), yang menyarankan bahwa seorang guru tidak hanya memikirkan "bagaimana cara siswa belajar", tetapi juga harus memikirkan "bagaimana cara membantu siswa untuk belajar yang terbaik", sehingga siswa dapat menguasai konsep Fisika sesuai dengan tujuan yang telah ditetapkan.

\section{Aktivitas siswa}

Aktivitas yang menunjukkan keterlibatan aktif siswa pada pembelajaran Fisika dengan model inkuiri terbimbing meliputi membaca bahan ajar, merumuskan masalah, merumuskan hipotesis, mengidentifikasi variabel, melaksanakan percobaan, mempresentasikan hasil percobaan, bertanya dan menanggapi pertanyaan teman/kelompok/guru. Sementara itu aktivitas yang berupa mendengarkan/memperhatikan penjelasan guru serta berperilaku tidak relevan tidak menunjukkan keterlibatan aktif siswa selama KBM.

Pembelajaran inkuiri merupakan aktivitas beraneka ragam yang meliputi observasi, membuat pertanyaan, memeriksa buku-buku dan sumber informasi lain untuk melihat apa yang telah diketahui; merencanakan penyelidikan; memeriksa kembali apa yang telah diketahui menurut bukti eksperimen; menggunakan alat untuk mengumpulkan, menganalisa, dan menginterpretasikan data, mengajukan jawaban, penjelasan dan prediksi, serta mengkomunikasikan hasil (National Science Education Standart). Berdasarkan analisis aktivitas siswa di atas, maka dapat diperoleh gambaran bahwa siswa telah melakukan aktivitas dominan selama melakukan penyelidikan. Siswa aktif 
dalam berlatih beberapa keterampilan proses sains melalui pembelajaran inkuiri.

\section{Kendala-kendala selama Kegiatan Belajar Mengajar}

Kendala atau hambatan yang dihadapi selama proses pembelajaran berlangsung diantaranya (a) keterbatasan waktu dalam KBM, (b) Siswa belum terbiasa dalam merumuskan masalah, membuat hipotesis, dan menentukan variabel, (c) Siswa mengalami kesulitan dalam menjawab pertanyaan analisis pada LKS, (d) Siswa tidak sabar untuk segera melakukan percobaan, (e) Siswa masih belum percaya diri ketika diminta oleh guru untuk menyampaikan hasil kerjanya di depan teman-teman sekelasnya ataupun untuk bertanya dan menyampaikan pendapat. Hambatan-hambatan tersebut dominan ditemukan pada pertemuan pertama dan dapat diminimalisir pada pertemuan selanjutnya.

\section{Keefektivan Perangkat Pembelajaran \\ 1. Respon Siswa}

Berdasarkan data dari kelas replikasi I, replikasi II, dan replikasi III diperoleh rata-rata persentase respon siswa yang dituangkan dalam gambar grafik sebagai berikut.

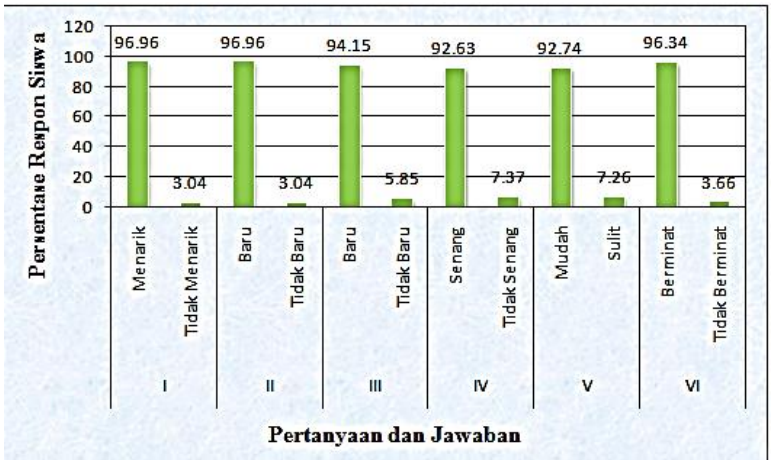

Gambar 7.. Rata-rata Persentase Respon Siswa Kelas Replikasi I, Replikasi II, dan Replikasi III

Berdasarkan hasil analisis angket respon siswa dapat dinyatakan bahwa sebagian besar siswa merespon pembelajaran Fisika dengan model inkuiri terbimbing untuk melatihkan keterampilan proses sains siswa sebagai pembelajaran yang menarik dan baru. Siswa memberikan respon yang sangat positif terhadap pembelajaran Fisika dengan model inkuiri terbimbing untuk melatihkan keterampilan proses sains, dapat dilihat dari persentase banyak siswa yang menyatakan positif pada setiap aspek $\geq 70 \%$ (Nieven dalam Sulasih dan Patahuddin, 2010).

\section{Tes Hasil Belajar Siswa}

Sebelum melakukan kegiatan pembelajaran dengan menerapkan model inkuiri terbimbing, siswa diberikan tes pendahuluan (pre-test) untuk mengetahui kemampuan awal siswa. Setelah diberikan perlakuan, siswa diberikan tes akhir (post-test) untuk mengetahui ketuntasan hasil belajar siswa. Nilai pretest dan posttest tersebut digunakan untuk mengukur apakah ada perbedaan hasil belajar siswa aspek pengetahuan antara sebelum dan sesudah dilakukan pembelajaran dengan model inkuiri terbimbing untuk melatihkan keterampilan proses sains siswa pada materi fluida statis. Nilai tersebut kemudian diolah untuk menghitung sensitivitas tes hasil belajar siswa aspek pengetahuan, ketuntasan indikator pembelajaran, dan ketuntasan individual siswa.

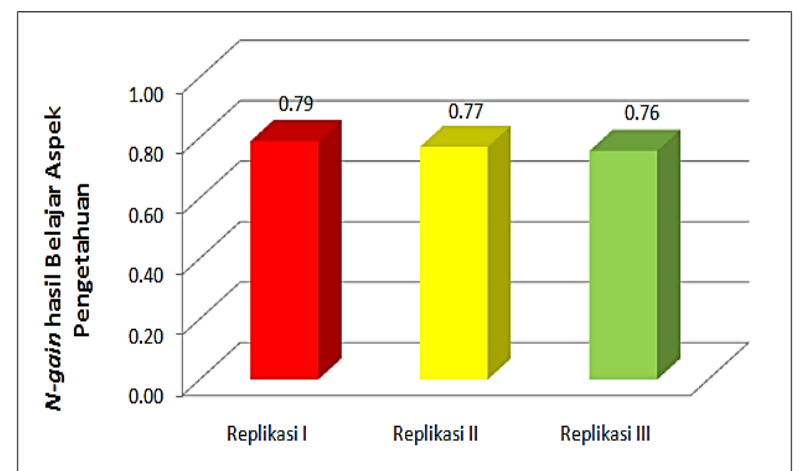

Gambar 8. Rata-rata N-Gain pada kelas replikasi I, II, dan III

Berdasarkan tes hasil belajar aspek pengetahuan sebelum dan sesudah pembelajaran didapatkan bahwa peningkatan skor ketuntasan belajar menunjukkan hasil yang signifikan dimana skor jawaban yang didapatkan siswa mengalami peningkatan, meskipun besar peningkatannya tidak sama. Hasil perhitungan gain skor ternormalisasi ( $N$-gain score) dinyatakan bahwa $N$-gain score tes hasil belajar aspek pengetahuan siswa tergolong tinggi karena memiliki skor rata-rata $\geq 0,7$ atau $70 \%$ yakni 0,79 atau $79 \%$ pada kelas replikasi I, 0,77 atau $77 \%$ pada kelas replikasi II, dan 0,76 atau $76 \%$ pada kelas replikasi III (Savinainen \& Scott, 2002). Hal ini menunjukkan bahwa model inkuiri terbimbing yang diterapkan dalam pembelajaran materi pokok fluida statis dapat meningkatkan hasil belajar siswa secara signifikan. Hasil penelitian ini mendukung penelitian yang telah dilakukan oleh Burhanuddin (2014) tentang pengembangan perangkat pembelajaran listrik dinamis dengan model inkuiri terbimbing, menunjukkan bahwa model inkuiri terbimbing dapat meningkatkan hasil belajar siswa, baik hasil belajar produk maupun hasil belajar proses.

Pembelajaran dengan model inkuiri terbimbing siswa juga dibantu tahapan-tahapannya sesuai dengan teori Vigotsky yang menekankan pada prinsip daerah perkembangan terdekat zone of proximal development (Nur, 2011). Guru menggunakan ide Vygotsky dalam mengajarkan sains dengan cara menetapkan tugas-tugas yang melampaui kemampuan siswa sendiri, tetapi yang dapat dicapai dengan bantuan guru. Awalnya apa yang dilakukan siswa tergantung pada guru, tetapi semakin mandiri setelah menguasai tugas belajar dan 
mendapatkan kontrol atas fungsi baru. Tugas guru adalah menyediakan lingkungan dan kondisi yang memungkinkan siswa belajar untuk menguasai keterampilan baru dan belajar hal baru (Khotimah, 2013).

\section{Tes Kinerja (Keterampilan Proses Sains)}

Selain diberikan tes hasil belajar pengetahuan, siswa juga diminta untuk melakukan tes kinerja untuk melihat keterampilan proses sains yang dimiliki siswa. Keterampilan proses yang diamati pada saat siswa melakukan tes kinerja meliputi: merumuskan masalah, merumuskan hipotesis, mengidentifikasi variabel, merancang eksperimen, melakukan eksperimen, menganalisis data, dan menyimpulkan hasil eksperimen. Hasil analisis tes kinerja pada kelas replikasi I, II, dan III disajikan sebagai berikut.

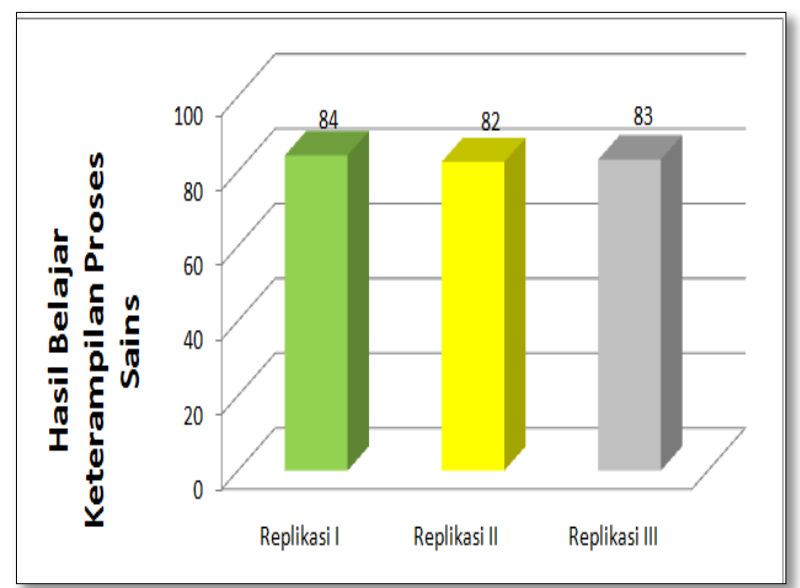

Gambar 9. Hasil belajar keterampilan proses sains pada kelas replikasi I, II, dan III

Dalam pembelajaran Fisika, siswa sebagai subjek belajar perlu dibekali dan dilatih untuk mengembangkan keterampilan proses sains melalui serangkaian proses dan kerja ilmiah, sehingga tumbuh dan tertanam sikap keilmuan pada diri siswa (Azis, 2014). Topik tes kinerja tersebut adalah tentang hukum Archimedes yaitu hubungan antara gaya Archimedes yang bekerja pada benda dengan massa jenis fluida.

Keterampilan proses sains siswa mencapai kategori baik dengan nilai rata-rata sebesar 83.31. Peneliti beranggapan bahwa hasil ini dicapai karena siswa terus dilatih selama tiga kali pertemuan untuk melakukan kegiatan eksperimen. Pada pertemuan pertama guru memodelkan terlebih dahulu bagaimana melakukan eksperimen dan menggunakan keterampilan proses. Hal ini dilakukan agar siswa memiliki gambaran-gambaran tentang apa yang akan dilakukan. Kemudian siswa melakukan eksperimen dengan bimbingan guru untuk merumuskan masalah, hipotesis, merumuskan hipotesis, menentukan variabel, merancang percobaan, mengambil data percobaan, menganalisis data, dan membuat kesimpulan. Walaupun siswa belum terbiasa dalam melakukan tes kinerja seperti hasil dalam angket respon dimana siswa merasa baru dalam merumuskan masalah, merumuskan hipotesis, merumuskan hipotesis, menentukan variabel, tetapi siswa sangat senang dengan pembelajaran yang melatihkan keterampilan proses yang dikemas dalam model inkuiri terbimbing. Ditambah lagi dengan kenyataan bahwa 92,74\% siswa (Gambar 7) merasa mudah mengikuti komponen-komponen keterampilan proses yang dilatihkan guru, siswa merasa mudah dalam merumuskan masalah, merumuskan hipotesis, menentukan variabel, melakukan percobaan, menganalisis data, dan membuat kesimpulan. Kemudahan-kemudahan yang dirasakan oleh siswa tersebut menjadi salah satu faktor yang menarik dalam kegiatan pembelajaran, sehingga siswa sangat berminat mengikuti pembelajaran selanjutnya dengan menggunakan model inkuiri terbimbing untuk melatihkan keterampilan proses sains siswa.

Secara keseluruhan, berdasarkan hasil ketuntasan tes kinerja siswa sudah cukup mampu untuk berlatih keterampilan proses melalui tes kinerja. Namun demikian, siswa masih memerlukan latihan secara berkelanjutan agar siswa terbiasa untuk menggunakan keterampilan proses dalam memecahkan masalahmasalah pada pembelajaran sains dan hasil belajar yang diharapkan dapat dicapai lebih optimal.

Pembelajaran dengan menggunakan model inkuiri terbimbing menunjukkan efektif untuk melatihkan keterampilan proses sains siswa, dibuktikan dari hasil penelitian yang dilakukan oleh Khotimah (2013) dan Chrisnawati (2013), yang menyatakan bahwa pembelajaran dengan inkuiri terbimbing efektif untuk melatihkan keterampilan proses sains siswa dan mengembangkan keterampilan psikomotorik.

Penerapan keterampilan proses pada pembelajaran Fisika yang disajikan dengan strategi dan metode yang tepat, diharapkan mampu membuat siswa terlatih dalam keterampilan yang bersifat ilmiah. Kegiatan pembelajaran seperti yang dilaksanakan dalam pembelajaran ini diharapkan mampu memenuhi harapan dari kurikulum 2013 yaitu adanya peningkatan dan keseimbangan antara kemampuan dan pengetahuan untuk hidup secara layak dari peserta didik yang meliputi aspek kompetensi sikap, pengetahuan, dan keterampilan.

Keterampilan proses sains yang diteliti ini sangat berkaitan erat dengan kurikulum 2013. Kurikulum ini mengamanatkan esensi pendekatan ilmiah dalam pembelajaran. Pendekatan ilmiah diyakini sebagai titian emas perkembangan dan pengembangan sikap, keterampilan, dan pengetahuan peserta didik. Metode ilmiah umumnya menempatkan fenomena unik dengan kajian spesifik dan detail untuk kemudian merumuskan simpulan umum. Untuk dapat disebut ilmiah, metode 
pencarian (method of inquiry) harus berbasis pada bukti-bukti dari objek yang dapat diobservasi, empiris, dan terukur dengan prinsip-prinsip penalaran yang spesifik. Karena itu, metode ilmiah umumnya memuat serial aktivitas pengoleksian data melalui observasi dan ekperimen, kemudian memformulasi dan menguji hipotesis (Mendikbud, 2013). Rangkaian kegiatan inilah yang dilatihkan oleh peneliti kepada siswa agar mereka terbiasa bekerja ilmiah, khususnya dalam pembelajaran Fisika.

\section{KESIMPULAN}

Berdasarkan analisis, pembahasan hasil, dan temuan penelitian, maka dapat disimpulkan bahwa pengembangan perangkat pembelajaran Fisika dengan model inkuiri terbimbing untuk melatihkan keterampilan proses sains siswa SMA pada materi fluida statis telah memenuhi syarat kevalidan, kepraktisan, dan keefektivan sehingga layak digunakan dalam proses pembelajaran.

Beberapa saran yang dapat peneliti kemukakan berdasarkan penelitian yang telah dilakukan dan hasil yang didapat adalah sebagai berikut:

1. Pembelajaran dengan model inkuiri terbimbing memerlukan pengaturan waktu seefektif mungkin sehingga pembelajaran dapat berlangsung sesuai dengan tujuan yang telah ditentukan.

2. Dalam merencanakan dan melaksanakan pembelajaran inkuiri, hendaknya guru menyiapkan alat-alat dan bahan percobaan yang akan digunakan dengan teliti, sehingga kegiatan penyelidikan dapat berjalan dengan lancar.

3. Guru perlu terus melatih siswanya untuk mengembangkan keterampilan proses sains melalui kegiatan-kegiatan percobaan supaya siswa terbiasa melakukannya.

Mengingat respon siswa terhadap model pembelajaran inkuiri terbimbing untuk melatihkan keterampilan proses sains positif, maka diharapkan model ini dapat diterapkan pada materi Fisika yang lain.

\section{REFERENSI}

Ahmadi, I.K. dan Amri, S. (2011). Pengembangan pembelajaran IPS terpadu. Jakarta: Prestasi Pustakarya.

Akbar, S. (2013). Instrumen perangkat pembelajaran. Bandung: Remaja Rosdakarya.

Amaliah, N. (2012). Standar pengembangan buku teks pelajaran. Jakarta: Wordpress.

Arends, R. (2012). Learning to teach, ninth edition. New York: Mc-Graw Hill.

Azis, M. (2014). Pengembangan perangkat pembelajaran inkuiri berbantuan program simulasi PhET untuk melatihkan keterampilan proses dan pemahaman konsep IPA (Makalah komprehensif tidak dipublikasikan). Universitas Negeri Surabaya.

Banchi, H. and Bell, R. (2008). The many levels of inquiry. (Online). Tersedia http://learningcenter.nsta.org/files/sc0810_26.pdf. Diakses tanggal 16 Januari 2014.

Bonnstetter, R.J. (1998). "Inquiry: learning from the past with an eye on the future". Electronic journal of science education. Vol. 3, No. 1.

Borich, D. (1994). Observation skill for effective teaching. New York: Macmilan Publising Company.

Burhanuddin. (2013). Pengembangan perangkat pembelajaran listrik dinamis dengan model inkuiri terbimbing untuk melatihkan keterampilan proses sains dan meningkatkan hasil belajar produk. (Tesis Magister Pendidikan Tidak dipublikasikan). Universitas Negeri Surabaya.

Chrisnawati, Z. (2013). Pengembangan perangkat pembelajaran inkuiri terbimbing untuk melatihkan keterampilan proses sains pada materi suhu dan kalor. (Tesis Magister Pendidikan Tidak dipublikasikan). Universitas Negeri Surabaya.

Collette, A.T. dan Chiapetta, E.L. (1994). Science instruction in the middle and secondary schools. New York: Macmillan Publising Company

Depdiknas. (2006). Peraturan menteri pendidikan nasional republik indonesia no.22 tahun 2006 tentang standar isi untuk satuan pendidikan dasar dan menengah. Jakarta: Dirjen Dikdasmen.

Eggen, P.D. and Kauchak, D.P. (1993). Strategy for teacher. Singapore: Allyn and Bacon

Giancoli, D.C. (2005). Fisika edisi keenam. Jakarta: Erlangga

Gronlund, N.T. (1982). Constucting achievment test. Engglewood Clifs, NJ: Prentice-Hall

Hake. (1999). Analyzing change/gain scores. (Online). Tersedia http://www. physicsindiana.edu/sdi/Analyzing-Change-Gain. pdf. Diakses 15 November 2013.

Hartati. (2014). Pengembangan perangkat pembelajaran kimia berbasis pendekatan keterampilan proses untuk meningkatkan penguasaan konsep dan keterampilan berpikir kritis siswa pada materi pokok koloid di SMA. (Tesis Magister Pendidikan Tidak dipublikasikan). Universitas Negeri Surabaya.

Herdian. (2010). Model pembelajaran inkuiri. Jakarta: Wordpress.

Herron, M.D. (1971). "The nature of scientific inquiry”. School Review, 79(2), 171-212.

Holil, A. (2008). Keterampilan proses. Jakarta: Wordpress.

Ibrahim, M. (2002). Pengembangan perangkat 
pembelajaran (pelatihan terintegrasi berbasis kompetensi guru mata pelajaran biologi). Jakarta: Depdiknas

Ibrahim, M. (2005). Asesmen berkelanjutan. Surabaya: Unesa University Press

Joyce, B., Weil, M., Calhoun, E. (2000). Models of teaching. 6th edition. Boston: Allyn and Bacon.

Kardi, S. (2002). Mengembangkan tes hasil belajar.. Surabaya: Universitas Negeri Surabaya.

Kardi, S. (2013). Model pembelajaran langsung, inkuiri, sains teknologi dan masyarakat. Surabaya: Pendidikan Sains PPs. Universitas Negeri Surabaya.

Khotimah, K. (2013). "Pengembangan perangkat pembelajaran berdasarkan model inkuiri terbimbing dalam rangka melatihkan keterampilan proses siswa" (Makalah komprehensif tidak dipublikasikan). Surabaya: Universitas Negeri Surabaya.

Koes, S. (2003). Strategi pembelajaran fisika, technical cooperation project for development of science and mathematics teaching for primary and secondary education in indonesia (IMSTEP), JICA. Malang: Universitas Negeri Malang.

Kuhlthau C.C., Maniotes L.K., Caspari A.K. (2007). Guided inquiry: learning in the 21st century school. London: Libraries Unlimited

Lesmono, A.D., Supeno, Riani, T. (2012). "Penerapan pendekatan keterampilan proses sains dengan model pembelajaran inkuiri terbimbing dalam pembelajaran fisika". Jurnal pendidikan fisika universitas jember. Vol. 1, No. 1, pp. 119-124.

Majid, A. (2007). Perencanaan pembelajaran. Bandung: PT Remaja Rosda Karya.

Meador. (2010). Introduction to inquiry physic a modified learning cycle curriculum. Bartlesville: Bartlesville High School. (Online). Tersedia http://inquiryphysics.org/, Diakses tanggal 16 Januari 2014.

Mendikbud. (2013). Diklat guru dalam rangka implementasi kurikulum 2013: konsep pendekatan scientific. Jakarta: Kementrian Pendidikan dan Kebudayaan.

Mendikbud. (2013). Standar proses pendidikan dasar dan menengah. Jakarta: Kementrian Pendidikan dan Kebudayaan.

National Academy of Sciences. (2000). Inquiry and the national science education standards: a guide for teaching and learning. Washington DC: National Academy Press

Nur, M. (2011). Model pembelajaran berdasarkan masalah. Pusat Sains dan Matematika Sekolah: Universitas Negeri Surabaya.

Nur, M. (2011). Modul keterampilan-keterampilan proses sains. Pusat Sains dan Matematika
Sekolah: Universitas Negeri Surabaya.

Nur, M. (2011). Teori-teori belajar. Pusat Sains dan Matematika Sekolah: Universitas Negeri Surabaya.

Nurfatita, N. (2011). Pengertian inkuiri. (Online). Tersedia http://nitanurtafita.blogspot.com. Diakses tanggal 11 Januari 2014.

Opara and Oguzor. (2011). "Inquiry instructional method and the school science currículum". Jurnal internasional. research journal of social sciences 3(3): 188-198, 2011. (halaman 188-198).

Prabowo. (2011). Metodologi penelitian (sains dan pendidikan sains). Surabaya: UNESA University Press.

Permendiknas Nomor 22. (2006). Standar kompetensi dan kompetensi dasar. Jakarta: Kementrian Pendidikan Nasional.

Program Pascasarjana Universitas Negeri Surabaya. (2014). Pedoman penulisan tesis dan disertasi. Surabaya.

Ratumanan, G.T. (2004). Belajar dan pembelajaran. Surabaya: UNESA University Press

Ratumanan, G.T., dan T, Laurens. (2006). Evaluasi hasil belajar yang relevan dengan kurikulum berbasis kompetensi. Surabaya: UNESA University Press

Rustaman, N.Y. (2005). "Perkembangan penelitian pembelajaran berbasis inkuiri dalam pendidikan sains". Makalah dipresentasikan dalam seminar nasional II himpunan ikatan sarjana dan pemerhati pendidikan IPA indonesia bekerjasama dengan FPMIPA universitas pendidikan indonesia, Bandung, tanggal 22 - 23 Juli 2005.

Slavin, R.E. (1994). Cooperative learning: theory, research, and practice. Second Edition. Boston: Allyn and Bacon.

Soegimin, W.W. (1993). Pengantar fisika statistik. Surabaya: ITS.

Sulasih dan Patahuddin, S. (2010). "Pengembangan perangkat pembelajaran tesselasi berbasis inkuiri dengan menggunakan ICT". Makalah SEACMA2. Surabaya: ITS.

Supriyatman dan Sukarno, (2014). "Improving science process skills (sps) science concepts mastery (SCM) prospective student teachers through inquiry learning instruction model by using interactive computer simulation". International journal of science and research (IJSR), India Online ISSN: 2319-7064. Volume 3 Issue 2, Februari 2014. www.ijsr.net

Sutrisno, (1997). Fisika dasar: mekanika. Bandung: Institut Teknologi Bandung.

Suwasono, P. (2011). "Upaya meningkatkan keterampilan proses sains mahasiswa fisika angkatan tahun 2010/2011 offering M kelas G 
melalui penerapan pembelajaran fisika model inkuiri terbimbing". Jurnal fisika dan pembelajarannya. Volume 15, Nomor 1.

TIM BSNP. (2007). Permendiknas nomor 41 tahun 2007 tentang standar proses untuk satuan pendidikan dasar dan menengah. Jakarta: BSNP.

Tribowo, P. (2013). Pengembangan perangkat pembelajaran dengan metode inkuiri terbimbing (guided inquiry) untuk melatihkan keterampilan berpikir kritis pada materi fluida statis (Tesis Magister Pendidikan Tidak dipublikasikan). Universitas Negeri Surabaya.

Triharyanti, C. (2012). "Pengembangan perangkat pembelajaran kuantum - think pair share (TPS) pada materi reaksi redoks". Prosiding Seminar Nasional Kimia Unesa.

Wardoyo, S.M. (2013). Pembelajaran konstruktivisme teori dan aplikasi pembelajaran dalam pembentukan karakter. Bandung: Alfabeta.
Wenning, C.J. (2005). "Levels of inquiry: hierarchies of pedagogical practices and inquiry processes". Journal of physics teacher education. Vol. 2, No. 3 ,

Wenning, C.J. (2010). "Using inquiry spectrum learning to teach science". Journal of pysics teacher education. Vol. 5, No. 3Summer. pp. 1120.

Wenning, C.J. (2011). "Experimental inquiry in introductory physics courses" dalam JPTEO (Journal of physics teacher education online) Illinois State University Physics Dept. USA. No. 2, Vol. 6. Halaman 2-7.

Wiyanto. (2006). "Potret Pembelajaran sains di SMP dan SMA". Jurnal pendidikan fisika indonesia. Volume 4, Nomor 2..

Young, H.D. and Freedman, R.A. (2002). Fisika universitas edisi kesepuluh jilid I. Jakarta: Erlangga. 